\title{
ISLAMIC VIEW OF HUMAN RIGHTS
}

\author{
Dini Nur Islamiyati*
}

* Affiliation:

Sultan Agung Islamic

University, Indonesia

email:

handiny6@gmail.com

\begin{abstract}
INTRODUCTION
Human Right is an important issue to be discussed, moreover in the West countries. This is because Human Right is talking about human being. Eventhough this concept was born and developed in the West, but East countries, which Islam becomes the majority, adapt this concept slowly to be included in the state law. Islamic concept is believed as the way of life by its adherents. Islam according to its adherents is a complete concept that rule every aspects in the human's life, no exception in the regulation of Human Right. Islam as a religion means rahmatan lil 'alamin, which means mercy for the universe, even in the social injustice Islam regulates about the concept of Human Right. This article purposes to know about the history of Human Right and how Islam views the concept of it.
\end{abstract}

\section{LITERATURE REVIEW The History of Human Right}

Human Right is the issue that is often discussed in the West countries especially. This issue is very crucial and important because it relates to the individual's freedom. Human Right issues are often used as 'a tool' to free individual from the certain social demands, for example a student reports his teacher because the punishment he got since he did not do his homework. The student's act above is more despicable action than the punishment itself. The student might use his Right as 'a weapon' to bring down the teacher, moreover government more concern to the children's right. However, if we flashback to the history of Human Right, we will see the sacred ideals of the Human Right.

The concept of Human Right could not be separated from the social tragedy happened in the Europe, where the proletariats were always oppressed and treated unfairly. Meanwhile, the borgouise, is like governs and nobles, acted arbitrarily to the people and irresponsible. Because of the tragedy, John Locke and Jean Jacques Rousseau started a rebellion to fight the problem, resulted France Revolution in 1789 (Ismail, 2009). After the tragedy, the awareness of Human Right began to grow in the society. Human has a right and obligation as a human being, be responsible, brotherhood, and freedom since they born (Ismail, 2009). 
Human Rights in Europe is characterized by the the birth of Magna Charta which contains the view that the king whose authority is absolute for all the people but the king himself is not bound by the law he made, then the king starts being held accountable in the eyes of the law. Meanhwile, in United State is characterized by The American of Independence by Rousseau and Montesquieu who confirms that human beings are essentially independent since in the womb, so it is illogical when they are born shackled by law.

Based on the explanation above, then it is clear that Human Rights issues are pure to protect every individuals who are oppressed, underestimated, and bullied in the society. Human Rights are also used as an alarm that human beings are equal essentially, eventhough all of them must be had different rights and obligations based on social perspective, but the right as the human being is the same. All have a life to determine their way of life, all have the right to live independently, and all have the right to express opinions for the common good. The act of intimidating, disturbing, injuring, and even killing, clearly has forced the rights of individuals as human beings. Therefore, this is very contrary to the principles of Human Rights.

Then what is the definition of Human Rights? There are many opinions that describe the definition of human rights itself, one of them is Philipus (1987). According to him, Human Rights are the rights owned by humans, not given from society or law, but solely because he is human, his dignity as a human being (Asnawi, 2012). As the name implies, Human Rights certainly cannot be separated from the discussion about human beings. How Human Rights strive to respect and uphold the dignity of human beings as humans. Human rights are also mentioned to have universal or comprehensive values, mean they are not limited to space and time (Asnawi, 2012).

Therefore during his life, starting when he was born until he died, his rights as a human being remained attached to him, even though he lived far away from his hometown, wherever his rights as a human were still valid and other people were not allowed to disturb him. In fact, even evil people still have Human Rights which are always inherented in themselves because they are human. However of course social conditions and natural law cannot treat themselves as before.

(Asnawi, 2012) describes the characterizations of Human Rights as below:

1. Human Rights are the part of human beings automatically

2. Human Rights are valid and owned by human beings

3. Individual's Rights could not be distrubed or destroyed

That is a glimpse of the origin of the birth of the Human Rights concept that emerged in the West as the birthplace of the understanding.

\section{METHOD}

Qualitative research is started by defining the general concept of the variable, the different hyphotesis could be the result of the research. Qualitative observes broadly and try to seek the pattern relation between the concept that have not decided yet in the beginning of the research. In this research, the data is matched by the theory used, the task of the researcher is to describe it deeply (Idrus, 2007). 


\section{RESULT AND DISCUSSION \\ Human Rights in Indonesia}

Even though it is universal, every country has its own interpretation dealing with human rights. Therefore, the rules are set in each country regarding the right to live and the penalties are different from each other, especially in Islamic and Western countries. Likewise in Indonesia, in Law as a state legal system has regulated Human Rights. Based on Law No. 39 of 1999 concerning Human Rights article 1, Human Rights are a set of rights that are inherented in the nature and the existence of human beings as the creatures of God Almighty are His gifts that must be respected, upheld, and protected by the state, law, government, and everyone, for the sake of honor and protection of human dignity (Darmadji, 2012).

Actually, understanding above has the same core with many opinions regarding the definition of Human Rights, that is maintaining, protecting, and respecting human existence as fellow beings of God. However, what distinguishes it is in how each country imposes penalties for people who violate Human Rights. This is regulated separately in the Law, such as the Law concerning torture, murder, harassment, etc.

Then how is the definition of Human Rights violations referred to in the Constituion? Based on Law No. 26 of 2000 concerning the Constitutional Court of Human Rights stipulates that Human Rights violations are every act of a person or group of people including state apparatus whether intentional or unintentional or negligence which legally reduces, obstructs, restricts, or revokes the Human Rights of a person or group of people guaranteed by the Law. This law is not obtained or it is feared that it will not get a legal settlement (Darmadji, 2012).

Then, institutionally, Indonesia already has institutions that regulate Human Rights issues, including (Darmadji, 2012):

1. The National Human Rights Committee was formed in 1993 with Presidential Decree No. 50 and has been stipulated in Law No. 39 of 1999

2. Establishment of the Office of the Minister of State for Human Rights in 1999 which has now changed to the Department of Justice and Human Rights

3. The Indonesian Child Protection Commission (KPAI) established based on Law No. 23 of 2002 concerning Child Protection in accordance with Republic of Indonesia Presidential Decree No. 77 of 2003 concerning Child Protection in order to increase the effectiveness of the implementation of child protection

4. Regional Indonesian Child Protection Commission (KPAID) in accordance with KPAI Letter No. 02 / KPAI / IX / 2004 concerning guidelines for establishing KPAID. This institution is independent and as needed in terms of its formation in each region

5. Implementation Committee for the National Action Plan for Human Rights (RANHAM).

There is a separate committee to run this institution which is fully responsible to the president.

Although Indonesia has had many institutions that regulate and manage Human Rights even to the regional level, it cannot be denied that cases involving Human Rights are still the most common cases. Starting from small cases such as theft, to severe cases such as slavery, persecution, abuse, and murder. This is understood because living in a society is not easy. Everyone has their own problems so they are forced to disturb the Human Rights of others, 
although there are also cases that are intentional. However, with several laws that have been created and institutions that have been implemented, the Constitution should at least reduce the frequency of cases occurring.

\section{Human Rights from Islamic View}

Islam actually knew more about the essence or values of Human Rights that had only been known in the West since 1400 centuries ago. Even though it is not a 'declaration' or formal affirmation that Islam recognizes Human Rights, the values contained in Islamic teachings clearly reflect that Islam is pro with Human Rights. It should be noted that the prophet Muhammad had previously mentioned the article on human rights in the Wada Hajj. This is summarized in a hadith "From Abu Umamah bin Tsa'labah, the Prophet said: 'Whoever seizes the rights of a Muslim, then he has the right to go to hell and unlawful to enter heaven ', A man asks: 'Even though it is something small, Apostle?' He replied: 'Even though it is only a piece of arak wood". In Islam, the essence of human being is the same, what makes it different is on the level of piety.

Human Rights in Islam are clearly stated in the interests of humanity, through Islamic sharia which is revealed through revelation. Muhammad Khalfullah Ahmad has given the understanding that Human Rights are inherented in human nature and fundamental as a mandate and gift of Allah SWT which must be protected and respected by every individual, society, or country. Even Ibn Rusyd emphasized that Human Rights in the perception of Islam had provided a form of protection, security, and anticipation of various basic Human Rights owned by every human being. The protection is presented in the form of anticipation of various things that will threaten the existence of the soul, the existence of honor and descent, the existence of material possessions, the existence of mind, and the existence of religion (Maududi, 2005).

The Islamic Human Rights system contains basic principles of equality, freedom and respect for fellow human beings. Equality means that Islam views all humans as equal and have the same position, have the same justice (proportional), the only advantage enjoyed by a human being on other humans is only determined by the level of piety. This is in accordance with the word of God in Sura Al-Hujarat verse 13, which means the following:

"O mankind, verily We created you from men and women, and We made you nations and tribes so that you would know each other. Surely the noblest of the people is the most pious." (AlQuran AL-IKHLAS, 2014).

\section{The Concept of Human Rights in Islam}

Basically, Human Rights in Islam are centered on five main things summarized in $\mathrm{Al}$ Dloruriyat Al-Khomsah or also called Al-Huquq Al-Insaniyah fi Al-Islam (Human Rights in Islam). This concept contains five main things that must be maintained by each individual, namely:

1. Hifdzu Al-Din (Respect for Religious Freedom)

Protection of religion and the beliefs held by each individual get a very high position and attention from the teachings of Islam. Universally, Islam gives each individual to choose and sort out the religion he will embrace. Although, Islam does offer teachings brought by the 
Prophet Muhammad to be understood, studied, and analyzed. So that the understanding and awareness of each individual is very preferred by looking at the concept of embracing Islam with full sincerity, and positive values that will be obtained. As has been confirmed by Allah SWT in QS. 2 (Al-Baqarah): 256,

"There is no compulsion to (enter) religion (Islam); indeed the right path is clear from the path that is astray. For whosoever denies Thagut, and believes in Allah, verily he has held on to a very strong knot that will not break. And Allah is Hearer, Knower." (Al-Quran AL-IKHLAS, 2014).

In addition, Allah SWT also stated that tolerance between religious people living side by side can be done with His assertive statement on QS. 109 (Al-Kafirun): 6,

"For you your religion, for me is my religion." (Al-Quran AL-IKHLAS, 2014).

However, internally, after someone has chosen Islam, the person concerned is asked to consistently follow the teachings he has followed. Allah SWT strictly forbids the act of riddah or apostasy, and includes it as a form of crime (Sabiq, 2009).

2. Hifdzu Al-Nafs Wa Al-'Ird (Respect for the Soul, the Right to Life and the Honor of the Individual)

Allah SWT conferred the right of life to all of His servants by not seeing race, gender, nation, or religion. In accordance with the words of the Prophet Muhammad, which was narrated by Imam Bukhari originating from 'Amr bin `Ash, which means: "A person who kills a person under agreement (a non-Muslim citizen in an Islamic state) will not kiss heaven even if he only smells the fragrance". In addition, Rasulullah SAW said: "Whoever kills a zimmi expert, indeed Allah forbids him from His heaven." (Narrated by An-Nasa i sourced by 'Amr bin `Ash).

According to Sheikh Syaukat Husain, Islam ordered his followers to respect this right to life, even if the baby was still in his mother's womb. More than that, Islam does not only pay attention to the glory and dignity of the human being when he is still alive, his dignity remains glorified, until his death, with his body taken care of, bathed, immortalized, sanctified and buried well and full of sincerity (Rochim, 2009).

\section{Hifdzu Al-Mal (Respect for Property)}

Speaking of property rights, Islam has taught every individual to be able to fulfill his personal needs and his family according to the achievements of his life skills. However, behind the assets they have, they contain the rights of others, especially the dhua fa from the poor, who are issued through Zakat, Infaq, Charity Funds (ZIS). This is in accordance with the word of Allah SWT QS. 51 (Adz-Dzariyat): 19,

"And on their assets there are rights of the poor who do not get a share." (Al-Quran ALIKHLAS, 2014).

The message of the verse states and confirms that anyone who asks for help and anyone who suffers from difficulties has the right to a portion of property and wealth of a Muslim, regardless of whether he is from this nation, or that, from any country and from any race he comes from (Rochim, 2009). 
In addition, Islam guarantees protection and security for the existence of each individual's assets, especially for property that is legally obtained. This includes the rights to be able to enjoy and consume assets, the right to invest in various businesses, the right to transfer, and the protection rights of other individuals living on their land (Rochim, 2009).

Islam always protects the property rights of each individual, as practiced by Rasulullah SAW and also continued by the Khulafa ar-Rashidun. As an example of a case that occurred during the Hunain War, the Prophet found a helmet owned by Sofwan bin Umayyah. When he was asked whether these hats would be taken without compensation? The Messenger of Allah answered: "All the steel caps that were lost during the battle would be replaced" (Rochim, 2009).

\section{Hifdzu Al-'Aql (Respect for Freedom of Thought)}

Islam conferred the right of freedom to think and the right to express opinions to all humanity. This freedom of expression is not only given to citizens when fighting tyranny, but also for each individual to freely express his opinion and at the same time express it in relation to various problems. Of course freedom of opinion here relates to efforts to socialize the deeds of goodness and virtue, and strive to appeal to and anticipate various acts of evil and injustice (Maududi, 2005).

The Messenger of Allah during his life had given his friends the freedom to express their opinions even though they differed from his personal opinions. The Prophet had forged the personalities of the companions in such a way that they could express dissent without hesitation. For example: when the Messenger of Allah asked the Companions to fight enemies in the city of Medina. The Companions argue that the position of the Companions must be at the location of the battlefield of Uhud. The opinions of the Companions were then chosen by Rasululah SAW that the position of Muslims and the Messenger of Allah in facing the enemy in the war of Uhud was in the location of Jabal Uhud not in the city of Medina (Rochim, 2009).

As another example, the Prophet invited to have a discussion and dialogue with his companions regarding the treatment of the prisoners of Badr War. At that time, there were two opinions of senior companions who appeared, the opinions of Abu Bakr Siddiq and the opinion of Umar bin Khattab. Abu Bakr submitted his opinion, to take the ransom (fidya) from the prisoners. As long as Umar bin Khattab argues more firmly, that the Badr prisoners must be killed. Responding to these two opinions, Rasulullah did ijtihad, by choosing the opinion of Abu Bakr Siddiq (receiving ransom from the prisoners of Badr War). In addition, the political tradition carried out by the Caliph Abu Bakr Siddiq and the Caliph Umar bin Khattab used to invite Muslims to ask for their criticism of various policies without hesitation.

\section{Hifdzu Al-Nasl (Must Guard the Descent)}

Family rights or the right to obtain these descents are the right to maintain the existence of a good name. It is implemented in the form of prohibited acts of adultery. However, in proving that the adultery must be supported by a valid testimony, namely four male witnesses. If the allegations cannot be proven, the accused adultery will be freed from the threat of punishment. Instead the accuser will be exposed to a severe threat. 
These five main things must be safeguarded by every Muslim in order to produce a more human life order, based on individual respect for individuals, individuals with society, society with society, communities with countries and religious communities with other religious communities.

\section{CONCLUSION}

Human Rights are the global issue that have discussed by people around the world. Many countries concern about this issue and legalize it into Constitution that must be obeyed by the citizen. However, Islam from the very beginning it exists has regulated its adherents dealing with Human Rights issue, even before the issue appears in the middle of society. Islam regulates five main things that must be maintained by each individual: Respect for Religious Freedom, Respect for the Soul, the Right to Life and the Honor of the Individual, Respect for Property, Respect for Freedom of Thought, and Must Guard the Descent.

\section{REFERENCES}

Al-Quran AL-IKHLAS. (2014). Jakarta: SAMAD.

Asnawi, H. S. (2012). Hak Asasi Manusia Islam dan Barat: Studi Kritik Hukum Pidana Islam dan Hukuman Mati, 1(1).

Darmadji, A. (2012). Islam dan Hak Asasi Manusia dalam Pendidikan. MIllah, 12(1).

Idrus, M. (2007). Metode Penelitian Ilmu-Ilmu Sosial (Pendekatan Kualitatif \& Kuantitatif). Yogyakarta: UII Press Yogyakarta.

Ismail. (2009). Hak Asasi Manusia Menurut Perspektif Islam, 43(I).

Maududi. (2005). Islamic Way of Life. Aligarh.

Rochim, A. (2009). HAK ASASI MANUSIA MENURUT PANDANGAN ISLAM DAN UUD 1945 PASCA AMANDEMEN (STUDI KOMPARASI UNIVERSITAS DAN PARTIKULARITAS HAM).

Sabiq, S. (2009). HAM Dalam Islam, 43(1). 